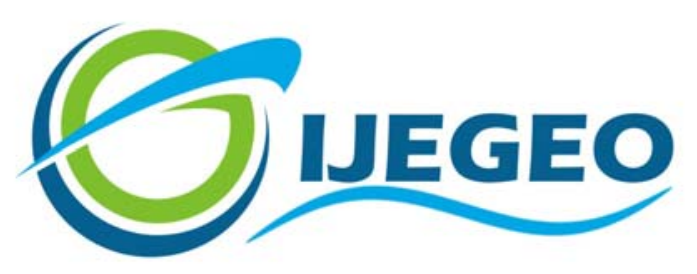

International Journal of Environment and Geoinformatics (IJEGEO) is an international, multidisciplinary, peer reviewed and certified open access journal.

\title{
Spatial Distribution of Snowfall Days in Turkey
}

\section{Telat Koç and Şeyda Kartum}

\section{Editors}

Prof. Dr. Cem Gazioğlu, Prof. Dr. Dursun Zafer Şeker, Prof. Dr. Ayşegül Tanık,

Prof. Dr. Şinasi Kaya, Assist. Prof. Dr. Volkan Demir

\section{Scientific Committee (2018)}

Dr. Abdullah Aksu, Prof. Dr. Bedri Alpar, Prof. Dr. Gülşen Altuğ, Prof. Dr. Lale Balas, Prof. Dr. Can Balas, Prof. Dr. Levent Bat, Prof. Dr. Bülent Bayram, Prof. Dr. Nuray Çağlar, Prof. Dr. Jadunandan Dash, Prof. Dr. A. Evren Erginal, Dr. Dieter Fritsch, Dr. Amin Gharehbaghi, Assoc. Prof. Dr. Tolga Görüm, Prof. Dr. Melike Gürel, Dr. Hakan Kaya , Prof. Dr. Fatmagül Kılıç, Assoc. Prof. Dr. Maged Marghany, Prof. Dr. Nebiye Musaoğlu, Prof. Dr. Masafumi Nakagawa, Prof. Dr. Haluk Özener, Prof. Dr. Erol Sarı, Prof. Dr. Elif Sertel, Prof. Dr. Nüket Sivri, Assoc. Prof. Dr. Füsun Balık Şanlı, Prof. Dr. Uğur Şanlı, Assoc. Prof. Dr. Hasan Özdemir, Prof. Dr. Taşkın Kavzoğlu, Msc. Mustafa Üstüner, Assoc. Prof. Dr. Oral Yağcı, Prof. Dr. Seyfettin Taş, Assoc. Prof. Dr. Ömer Suat Taşkın, Assoc. Prof. Dr. İ. Noyan Yılmaz, Dr. Baki Yokeş, Dr. Sibel Zeki 


\title{
Spatial Distribution of Snowfall Days in Turkey
}

\author{
Telat Koç ${ }^{1,}$, Şeyda Kartum ${ }^{2 *}$ \\ ${ }^{1}$ Çanakkale Onsekiz Mart University, Faculty of Sciences and Arts, Department of Geography \\ ${ }^{2}$ Çanakkale Onsekiz Mart University, Faculty of Sciences and Arts, Department of Geography \\ Corresponding author* Tel: +905072053301 \\ Received \\ E-mail: seydakartum@hotmail.com \\ Accepted
}

\begin{abstract}
In observing the effects of global climate change on Turkey, it is important to determine the frequency of snowfall and its spatial distribution. This study concerns the spatial distribution of snowy days in Turkey utilizing measurements provided by the Turkish State Meteorological Service. The homogeneity of 217 stationspecific and constructed data was analyzed using Kruskal-Wallis Test. The longest data sets are 75 years old covering the years 1932-2006 while the shortest is 25 year-old data covering 1982-2006. Figures were mapped with GIS taking the mean values and variability coefficients of the long-term data from the stations. The factors that affect spatial distribution and variance of snowfall days in Turkey are location, continentality, altitude and exposure. The snowfall observed in most of the northeast Anatolia stations decreases to the south and west. Due to local climatic conditions, snowy days increase in Edirne and Kastamonu, while Iğdır and Malatya decrease towards the periphery. This introductory study on the climatology of snowfall days in Turkey is considered a guide for handling data, taking precautions, and creating solutions. The study's findings will serve as a basis for interpreting the results of future studies.
\end{abstract}

Keywords: Climate, Climate change, non-parametric tests, snow, snowfall, Turkey

\section{Introduction}

Global warming as a result of human interaction with the environment (Türkeş, $2008 \mathrm{a}-\mathrm{b})$ and the resulting aridification and drought are among the main problems for which solutions are sought. Therefore, determining the characteristics of snowfall in Turkey and its spatial distribution has become a necessity on the scientific agenda, as snowfall is one of the components making up the natural environment, with an important role in the Water Cycle. By exploring the characteristics of snowfall, it will be easier to understand the natural environment and explain its interaction with the social environment. In climatology, the observation, recording, have included research on snowfall days. analysis and interpretation of snow Older studies on snowfall are general, meteorology is difficult due to the many covering all of Turkey, while current studies physical factors affecting snowfall, such as have a much narrower scope. The distance from the sea, altitude, orography and results of studies previously carried out orientation (Gürer, 1992). Because of its regarding the spatial distribution of location and multi-component climatic snowfall, both in Turkey and worldwide, environment, Turkey is one of the

countries most susceptible to climate change. Different regions will be affected in different ways and at different levels by global warming due to orographic characteristics and the fact that it is surrounded by seas on three sides and has a fragmented topography (Türkeş, 2001; Öztürk, 2002). For this reason, short-term forecasting of weather events is very important. In turn, this is dependent on accurate information on atmospheric conditions (Türkeş, 2008a). Therefore, in terms of understanding climatic features and revealing the extent of climate change, it is necessary to know the spatial dispersion of snow climatology. Previous studies have tended to concentrate (n) 
Klein (1949) evaluated observations of snowfall in Canada and emphasized that snowfall in Canada showed both spatial and seasonal variations. Öngör (1955) provided methodological information on how observations of snowfall were carried out and how this data could be evaluated. Erinç (1957) provided information on the measurement of snow as a climatic element and how snowfall and the characteristics of snow were interpreted, providing the first study of these features covering the whole of Turkey. Onur (1964) examined snowfall days, days with snow cover and snow depth throughout Turkey using data from the period 1930-1958. In the study of Gürer (1992), the processes of measurement, data collection, correction of measurement errors, analyses, synthesis and application were explained together with the then- existing snow observation network, places of measurement, correlation between different measurements, and various types of instruments were introduced and examined. In his study on the general application of snowfall observation methods, Crurch (1933) detailed snowfall observation practices in Canada. Barry et al. (1995) underlined the possibility of changes in the characteristics of snow cover due to global warming as a result of the increase in greenhouse gases in the $20^{\text {th }}$ century. Brown (2000) discussed the variance in snow cover between 1915 and 1997 using snow cover data in the northern hemisphere between the $40^{\text {th }}$ and $60^{\text {th }}$ parallels covering the USA, SSCB and China. Akyürek and Şorman (2002) studied the features of snow cover in the upper section of the Euphrates River Basin utilizing data obtained by satellites. Laternser and Schneebeli (2003) researched the variance in average snow depth, days with snow cover and snowfall days in the Swiss Alps 1931-1999. It was observed that there was a gradual increase in snowfall until the beginning of the 1980s, especially during the 1950s and 1970s; however, a statistically significant decrease was observed from the beginning of the 1980 s to the end of the century.

On the other hand, snow studies by Turkish State Meteorological Service (TSMS) (Commission, 1970) included only snow cover measurements but did not explore snowfall days. Turkey has never been assessed within the scope of worldwide studies or as part of the northern hemisphere or Eurasia. Research studies conducted by Koç and Kartum (2008 and 2011), Kartum and Koç (2009) and Kartum, Koç and Türkes (2011) are an introduction to snowfall days climatology in Turkey. Koç and Kartum (2008) examined the characteristics and spatial distribution of snowy days in Turkey with maps prepared according to season. Kartum and Koç (2009) investigated spatial and temporal changes to snowfall in Thrace. They detected a decreasing trend of snowy days at all stations in winter (December-JanuaryFebruary). This was found to be statistically significant especially in Kırklareli and Lüleburgaz. Koç and Kartum (2011) investigated how snowy days reveal their progress over time in a study entitled "Temporal change characteristics of snowfall days in Turkey". They noted a predominantly decreasing tendency in stations on snowy days over the long-term. Kartum, Koç and Türkeş (2011) investigated changes and trends observed at the beginning and end dates of snowfall in Turkey. The study detected significant decreases in snowy periods in general terms.

In this study, we attempt to determine the spatial distribution of snowfall days in Turkey, which is among the countries that could be extensively affected by global warming. For this purpose, maps were produced after statistical analysis of the data had been completed. It was observed that spatial differentiation is prominent on snowfall days and this differentiation is shaped by Turkey's location and physical geographical features. It is thought that this study will contribute to an understanding of the Turkish climate in general and specifically, the features of Turkey's snow climatology. Furthermore, it aims to provide basic data that is currently lacking for the sustainable management of water resources.

\section{Materials and Methods}

In this study, data on snowfall days provided by Turkish State Meteorological Service (TSMS) were utilized. The data cover the period from when measurements were first made to the end of 2006. Snowfall data obtained from 280 meteorological stations of TSMS were examined; observation times and data were obtained paying special attention that the rate of 
missing data did not exceed 5\%. In this way, 219 stations were determined as appropriate for use in the study. The longest period of observation at these stations was 75 years while the shortest period was 25 years. The observation periods were grouped into 5-year intervals. Because of homogeneity analysis tests applied to the stations, Nallihan and Uzunköprü stations, whose homogeneities were disrupted, were eliminated. At this stage, the total number of stations whose data could be used was 186. Balıkesir station, although measurements continued only until 1998, was then included due to its long observation period (55 years).
Moreover, Kartal and Trabzon stations, which made observations until 2004 and 2005, respectively, were included in the study due to the regularity of their data. At this point, the Mediterranean and Aegean regions appeared empty on the map generated since measurements in these regions were not regular and the rate of missing data was over $5 \%$ for both regions. In order to correct the visual deficiency caused by this, we attempted to give a general perspective using short-term data from 31 stations. In total, therefore, 217 stations were included within the scope of the study (Fig. 1).

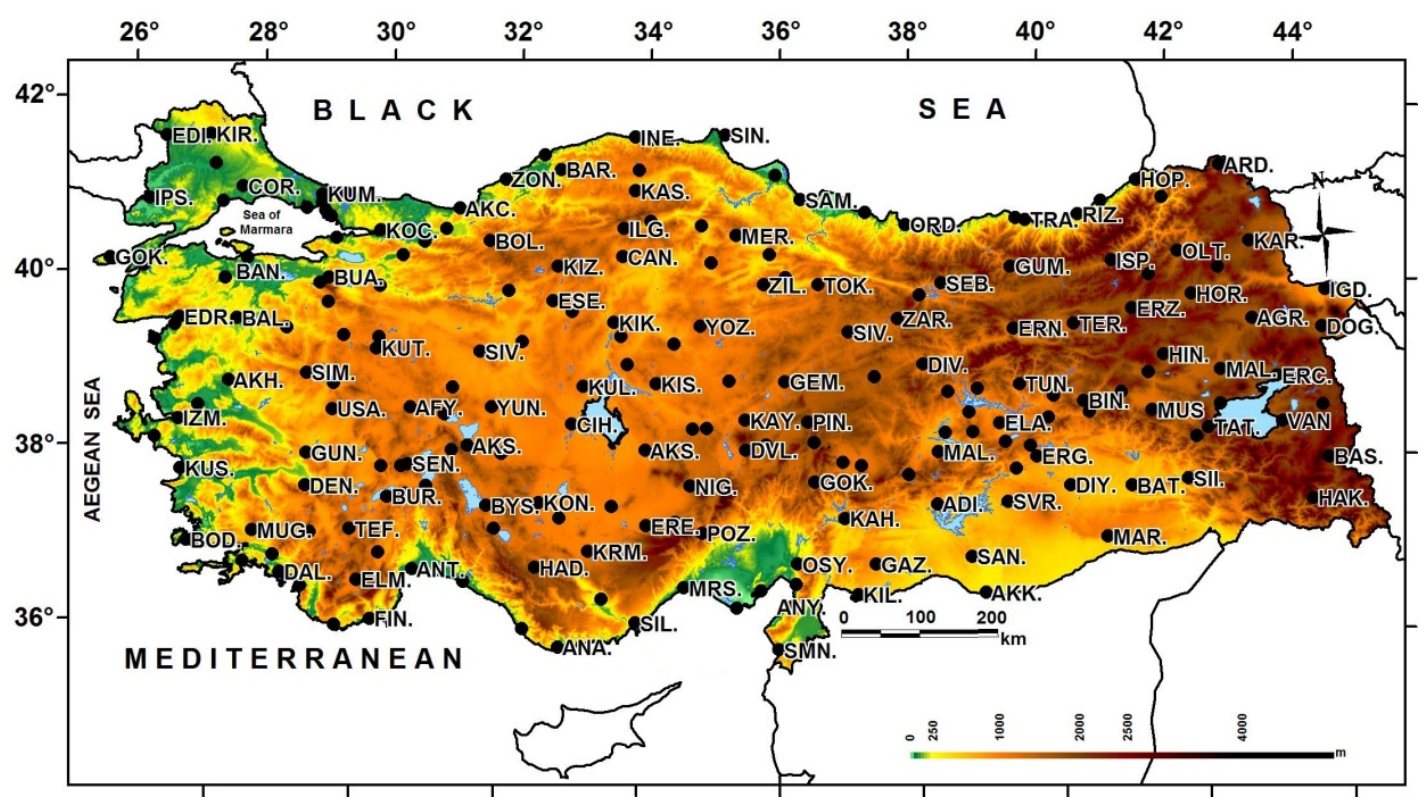

Fig 1. Geographical distribution of the 217 climatological and meteorological stations (mostly major climatology and synoptic meteorology) in Turkey included in the study.

In order to determine the homogeneity of the data on snowfall days, Kruskal-Wallis Homogeneity Test was applied, which is a nonparametric test used to verify the homogeneity of averages and variations.

Instead of the real observations in each series being analyzed in the Test, sequence numbers $(m)$ in the total sequenced series generated by consecutive ordering from largest to smallest are used (Türkeş, 2004).

Test sample value $X_{k}$ is calculated with the following equation:

$$
X k=\left[\frac{12}{n(n+1)} \sum_{j=1}^{k} \frac{R_{j}^{2}}{n_{j}}\right]-3(n+1)
$$

Before calculating the test sample value, it should be checked by this equation to see whether the $R_{j}$ value is valid or not (Türkeş 2004):

$\sum_{j=1}^{k} R j=\frac{n(n+1)}{2}$ 
In order to examine the homogeneity of averages, the hypotheses below were considered:

$\mathrm{H}_{0}=$ the average of the observation series is homogeneous.

$\mathrm{H}_{\mathrm{a}}=$ the average of the observation series is not homogeneous.

Under the null hypothesis that averages are homogeneous, $\mathrm{X}_{\mathrm{k}}$ sample value, with $(\mathrm{k}-1)$ degree of freedom, is distributed as $\left(\chi^{2}\right)$. The acceptance or refusal of the null hypothesis is dependent on the critical value of $\chi^{2}$, which is found from the $\chi^{2}$ table according to $\mathrm{f}=(\mathrm{k}-1)$ degree of freedom at the requested level of significance $[\alpha=0.05(5 \%)$ or $\alpha=0.01(1 \%)]$

The null hypothesis is rejected for an $\mathrm{X}_{\mathrm{k}}$ greater value $\left(\mathrm{X}_{\mathrm{k}} \geq \chi^{2}\right)$.

If some of the original values in the total sequenced series are equal, the $\mathrm{X}_{\mathrm{k}}$ test sample value should be corrected by being divided by the adjustment coefficient, calculated with the following equation:

$$
C c=1-\frac{\sum T}{n^{3}-n}
$$

Here, $\sum T$,

$\mathrm{T}=(\mathrm{t} 3-\mathrm{t}) * \mathrm{~K}$

gives us the totality of all groups of equal values given that $(\mathrm{t})$ is the number of equal values in a group of equal values (Türkeş, 2004). Thereby, as a result of analysis based on monthly totals of snowfall days in Turkey, 25 stations with nonhomogeneous data were determined.

The simultaneous occurrence of data set homogeneity break points suggests that these are natural fractures in the climate. These dates were first examined with the SPI drought index, in addition to climate indicators such as mean temperature and precipitation normals (19812010), teleconnection oscillations and seawater temperature were found to be compatible (Demircan et al., 2015).

After determination of stations that could be used in the study, the seasonal and annual arithmetic averages of snowfall days were calculated. Geographical Information Systems (GIS) maps were prepared and spatial distribution was plotted. During the preparation of these spatial distribution maps of the snowfall days in Turkey, raster maps (0.01 degrees) consisting of $1 \mathrm{~km}^{2}$ grids were created with GIS. Making use of this, raster maps of equal snowfall days were created.

We aimed to identify the average snowfall days (seasonal and annual) and hence determine the distribution. By calculating the coefficient of variability of snowfall days in Turkey (seasonally and annually), the persistence of snowfall was determined. Then, these results were mapped one by one. If the standard deviations of the series compared are expressed as a percentage of the average values of the series to which they are related, the differences of units of measurement in comparisons and inconveniences stemming from the size of the observation value can be avoided. The measure of variability calculated with this approach is called coefficient of variation, abbreviated as "CV” (Yüzer et al., 2003).

$$
C V(x)=\frac{\sigma}{\bar{x}} * 100
$$

\section{Results}

In this section, in addition to seasonal (winterspring-summer-autumn) analysis and evaluation, a separate analysis of the winter period (November - December - January - February - March) and an annual analysis are presented.

\section{Winter}

The areas where the number of snowfall days is highest in the winter months (DecemberJanuary-February) are as follows: The eastern Black Sea mountains, northeastern Anatolian plateau; Tahtal1-Mercan mountain ranges (Anatolian Diagonal), Taurus Mountains and areas around Hakkari. The mountainous regions where the number of snowfall days is high extend westwards with the western Black Sea mountains (significant especially around Kastamonu). The central-western Anatolian plateaus are also areas where the number of snowfall days increases. In addition to the high number of snowfall days in mountainous regions, a significant increase in the number of snowfall days on single mountains was determined compared to the surrounding areas, as in the case of Mount Uludağ (40 days at the mountain station) (Fig. 2). A decrease in the number of snowfall days was observed in areas at a lower altitude, such as Iğdır Plain, Malatya-Elazığ region (Keban Dam 
and its surroundings) and the Lake Van region, compared to the surrounding regions with a higher number of snowfall days (Fig. 2).

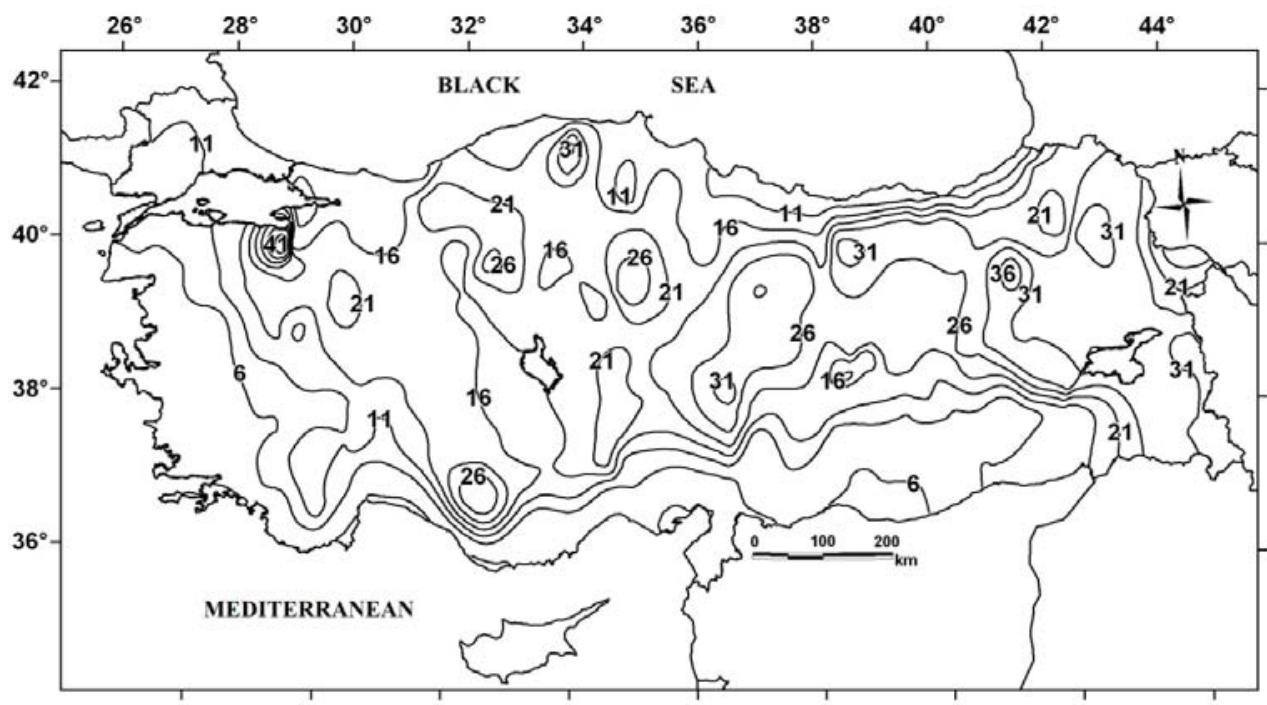

Fig 2. Spatial distribution of snowy days in 3-month winter season: long-term average number of days.

Little or no snowfall was observed in the coastal strips of the Mediterranean and Aegean regions. Although the southeastern Anatolian region is located at the same latitude as the Mediterranean region, it is noteworthy for having more snowfall days comparatively because of the continentality effect (Fig. 2). In Thrace, although the altitude is not high, an increase was observed under the influence of continentality. It is thought that Edirne province, its surroundings and the Yildiz Mountains are the areas first affected by mobile depressions coming from the northwest after passing through eastern Europe, which increases the number of snowfall days in this region. Although the number of snowfall days increases in the coastal strip of the western section of the Black Sea region, it decreases in the central Black Sea section. Exposure and altitude are thought to be the factors leading to more snowfall in higher regions facing the northwest. The increase in the number of snowfall days in the transition zone from the eastern Black Sea coastal area to eastern Anatolia can also be explained by the existence of eastern Anatolian mountains, with an altitude of more than 4000 meters.
An increase in the number of snowfall days was observed in the eastern Taurus Mountains surrounding the Gulf of Antalya (Fig. 2). In addition to this, the increase in the number of snowfall days (30) in the Geyik Mountains to the east of the Gulf of Antalya is believed to stem from precipitation, which increases due to exposure taking the form of rain in the coastal strip, and transforms into snow at higher altitudes (the mountains extend in a northwestsoutheast direction forming a barrier against mobile depressions coming from the southwest).

In Figure 3, the spatial distribution of the coefficient of variation of snowfall days in Turkey is shown. It can be seen that there is a significant increase from northeast to southwest. In areas where factors increasing the probability of snowfall days (location, continentality, altitude and exposure) are more effective, the coefficient of variation of the number of snowfall days decreases, while this increases under opposite conditions. As a result, variation increases were observed in northeastern Anatolia while variation decreased in southwestern Anatolia. In Figure 3, in addition to the peak regions of northeastern and southwestern Anatolia, the situation of other 
areas is shown, in order of importance, in relation to the factors of continentality, altitude, location and exposure.

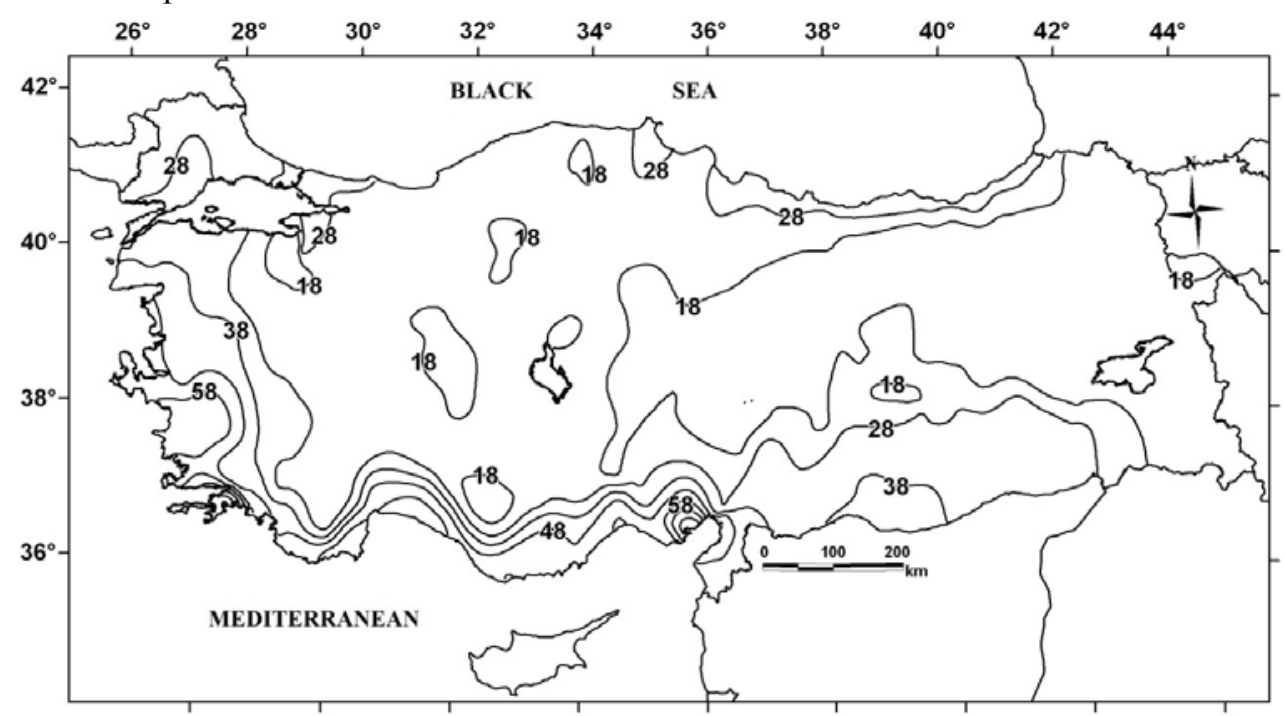

Fig 3. Spatial distribution of snowy days in 3-month winter season: coefficient of variation (\%).

\section{Winter Period}

While the distribution map of snowfall days in Turkey during the extended winter period (November-December-January-February-

March) shows a numerical increase compared to the winter season only (December-JanuaryFebruary), it parallels the situation in terms of spatial distribution characteristics (Figs. 2 and 4). Numerical increases are related to the addition of the numerical values of autumn's last month (November), and spring's first month (March) to the winter period map. From this perspective, the winter period reflects the snowfall period more effectively. In this period, Mt. Uludağ receives special attention as an area where the highest number of snowfall days is observed. With the inclusion of the autumn and spring months, the number of snowfall days observed in Uludağ Station increases by 20 days, underlying the importance of snowfall days in those seasons. Similarly, there is an increase of 20 days in eastern Anatolia, leading to a total of 55days (Fig. 4). In a similar manner, increases are observed along the whole of the Black Sea region. Areas that experience important increases in the number of snowfall days with the inclusion of autumn and spring are areas that have the highest number of snowfall days. In these regions, snowfall days in autumn and spring are as important as snowfall days in winter. Another important point is the fact that in areas where the number of snowfall days is low, the addition of autumn and spring months has almost no effect. It can be concluded that the probability of snowfall in autumn and spring is very low in such areas.

When the spatial distribution of the coefficient of variation on snowfall days in the winter period is evaluated, a significant increase is noticed moving from the northeast toward the southwest. The map for the winter period also indicates that in areas where factors increasing the probability of snowfall days (location, continentality, altitude and exposure) are more effective, the coefficient of variation of the number of snowfall days decreases, while it increases under opposite conditions (Fig. 5). Similarly, variation increases were observed in northeastern Anatolia while variation decreased in southwestern Anatolia. 


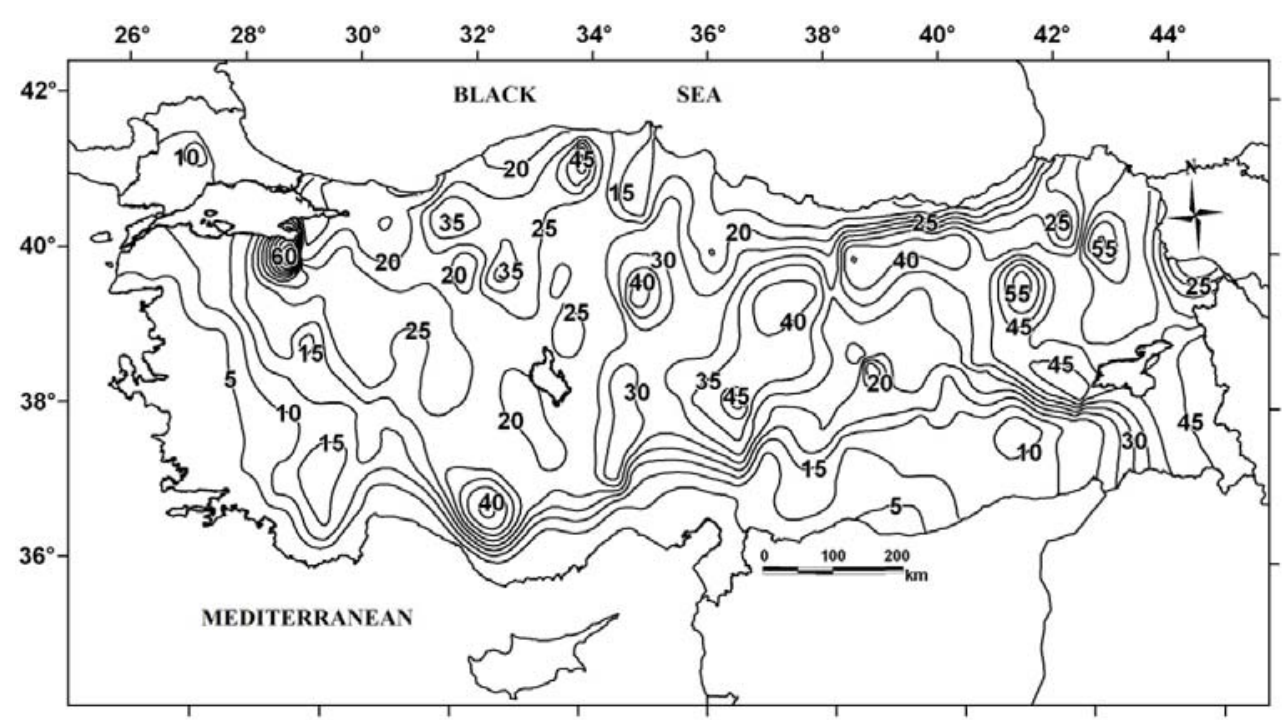

Fig 4. Spatial distribution of snowy days in 5-month winter period: long-term average number of days.

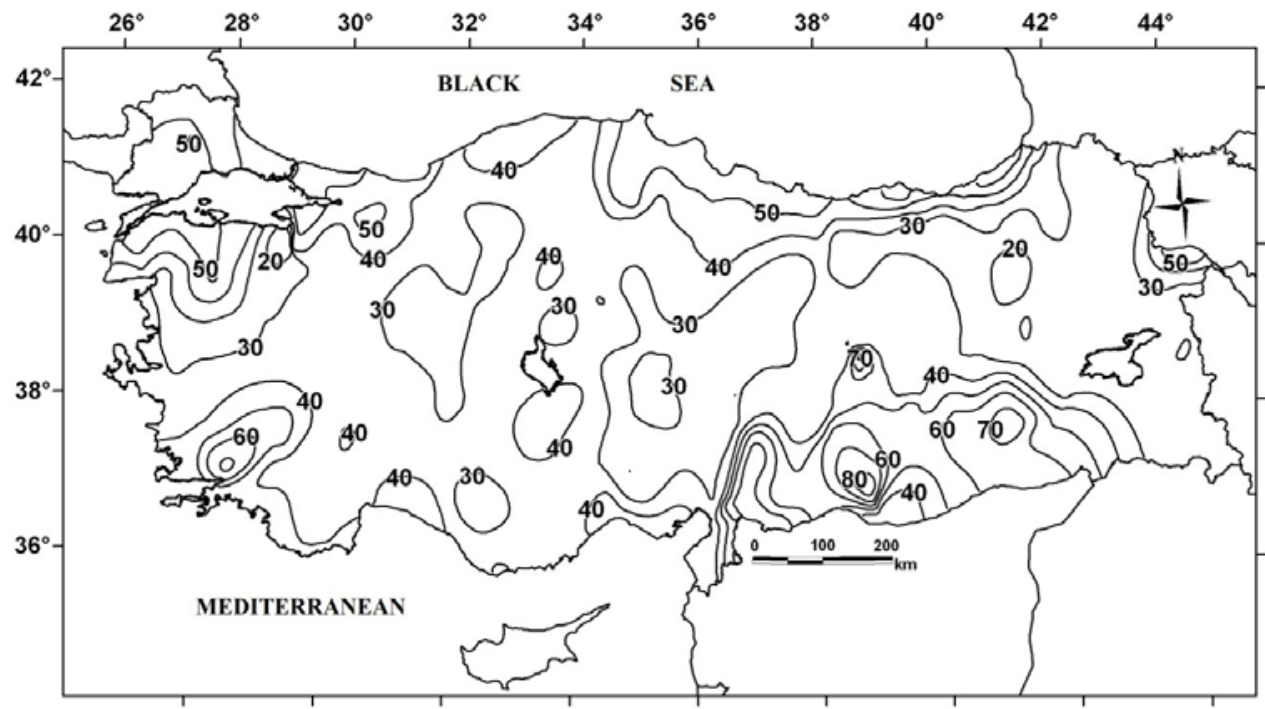

Fig 5. Spatial distribution of snowy days in 5-month winter period: coefficient of variation (\%).

\section{Spring}

The spring (March-April-May) season is observed as a milder continuation of winter in eastern Anatolia and in regions of high altitude. As mentioned in Koç's (1999) study, seasons determined by mathematical methods do not reflect the natural seasons experienced in every region or area. For this reason, although the distribution of snowfall days in spring in Turkey shares similarities with winter, the number of snowfall days recorded at metereological stations in eastern Anatolia decreases from 35 to 24 . Snowfall days in spring are intense in the following locations: the eastern Black Sea mountains, northeastern Anatolian plateau, Tahtali-Mercan mountain ranges (Anatolian Diagonal), Taurus Mountains and areas around Hakkari (Fig. 6). While the number of snowfall days in the Aegean and Mediterranean regions was recorded as zero, the number tends to increase in southeastern Anatolia in spring compared to winter. Another interesting point is the distribution in centralwestern Anatolia, where the number of snowfall days is 5 days in winter; and this figure acts as a border with the neighbouring 
Aegean region. In spring this border moves toward the inner parts of central-western Anatolia and the number of snowfall days decreases to 3 (Fig. 6).

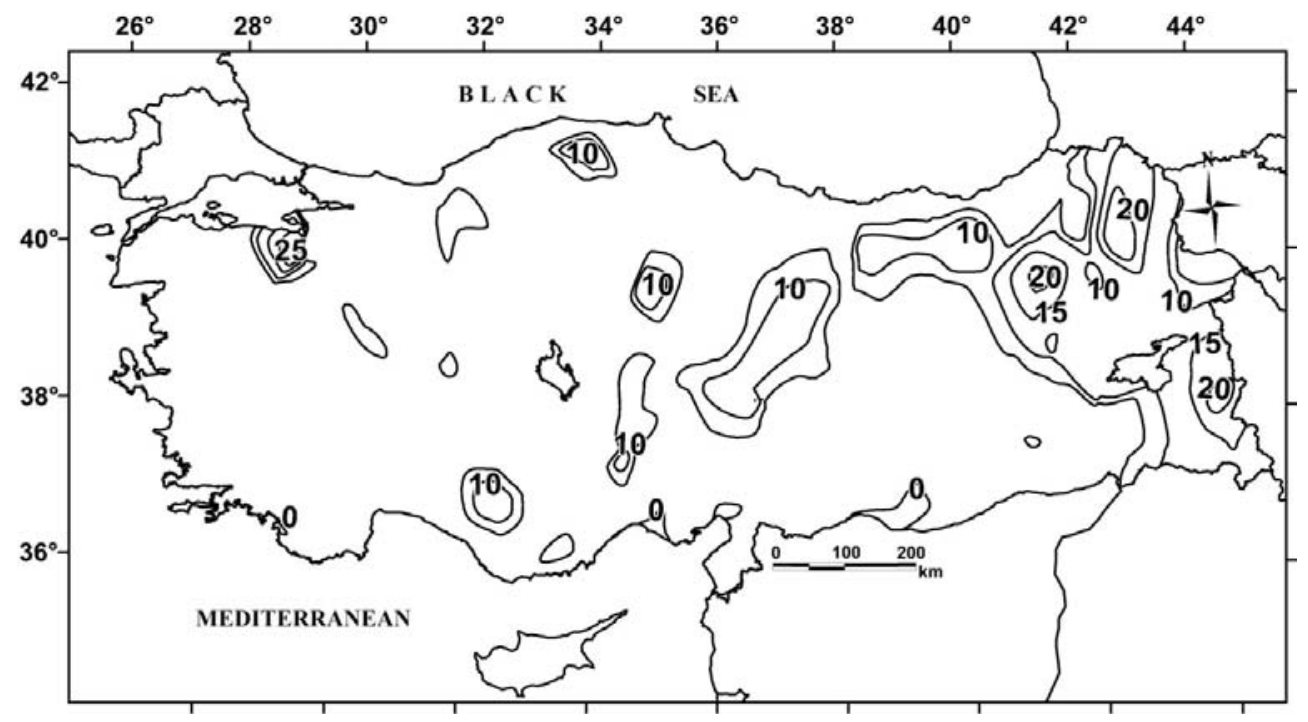

Fig 6. Spatial distribution of snowy days in 3-month spring season: long-term average number of days.

In Figure 7, showing the spatial distribution of the coefficient of variation of snowfall days in Turkey, a significant increase from northeast toward the southeast is striking. Since the effect of factors increasing the probability of snowfall days (location, continentality, altitude, exposure) did not change, there were no important differences on the maps in the coefficient of variance. As a result, the variation decreases in northeastern Anatolia while it increases in southwestern Anatolia.

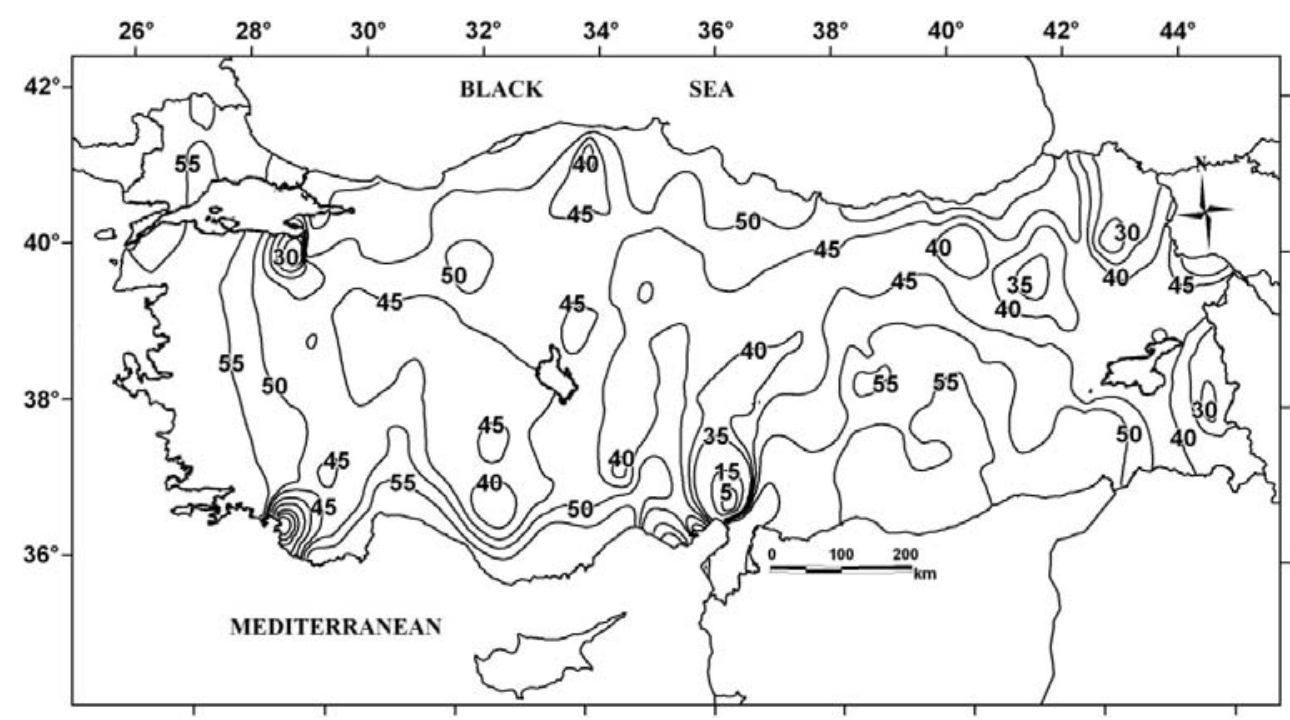

Fig 7. Spatial distribution of snowy days in 3-month spring season: coefficient of variation (\%). Summer 
Summer (June-July-August) is a period difficult to explain in terms of the number of snowfall days because generally, no snowfall is observed anywhere in Turkey during this season. Nevertheless, incidental snowfall observations made in the stations of Uludag and the eastern Anatolian region resulted in very low averages for these areas.

\section{Autumn}

After summer, autumn (September-OctoberNovember) is the season during which the lowest number of snowfall days is observed. When compared to spring, we can link this to the fact that the surface temperature does not drop much in autumn. It can be claimed that in Turkey, summer appears to extend its effect into autumn. In autumn, the highest score is for the Uludağ station with 12 days while the highest score in eastern Anatolia was measured as 9 days (Fig. 8). The Aegean, Mediterranean and south Anatolian regions have the same outlook as these areas where observations of zero (0) days are generally dominant (Fig. 8). In the western part of central Anatolia, the number of snowfall days, which is 5 in winter, decreases to 3 days in spring and less than 2 days in autumn. As a result, in this season the borderline of snowfall days moves further to the west. Though there is a decrease of the coefficient of variance of snowfall days in Turkey from southeast to northwest, in a manner similar to the general picture; since there are no reasons for change in the Aegean and Mediterranean regions, the value in these regions is zero (0). In the Taurus Mountains zone, which is just behind this line, the variation increased, and due to changes over short distances, the lines for the coefficient of variance gain a sudden intensity (Fig. 9).

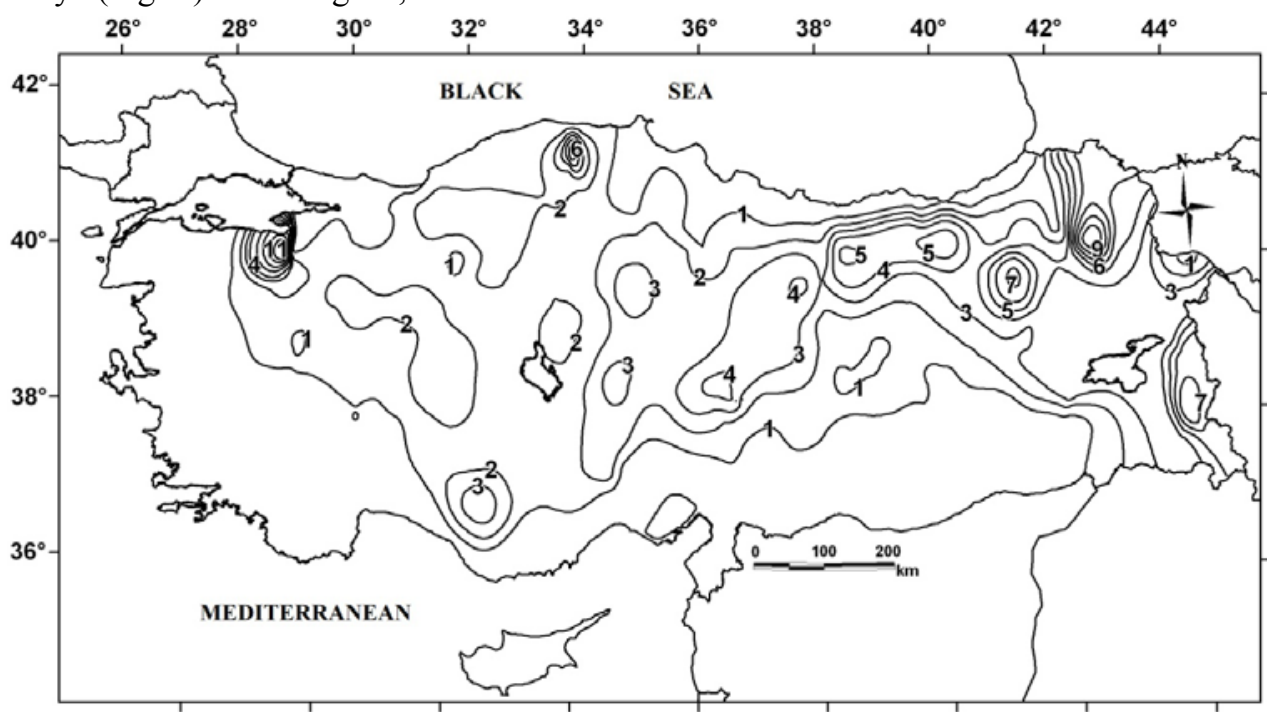

Fig 8. Spatial distribution of snowy days in 3-month autumn season: long-term average number of days. 


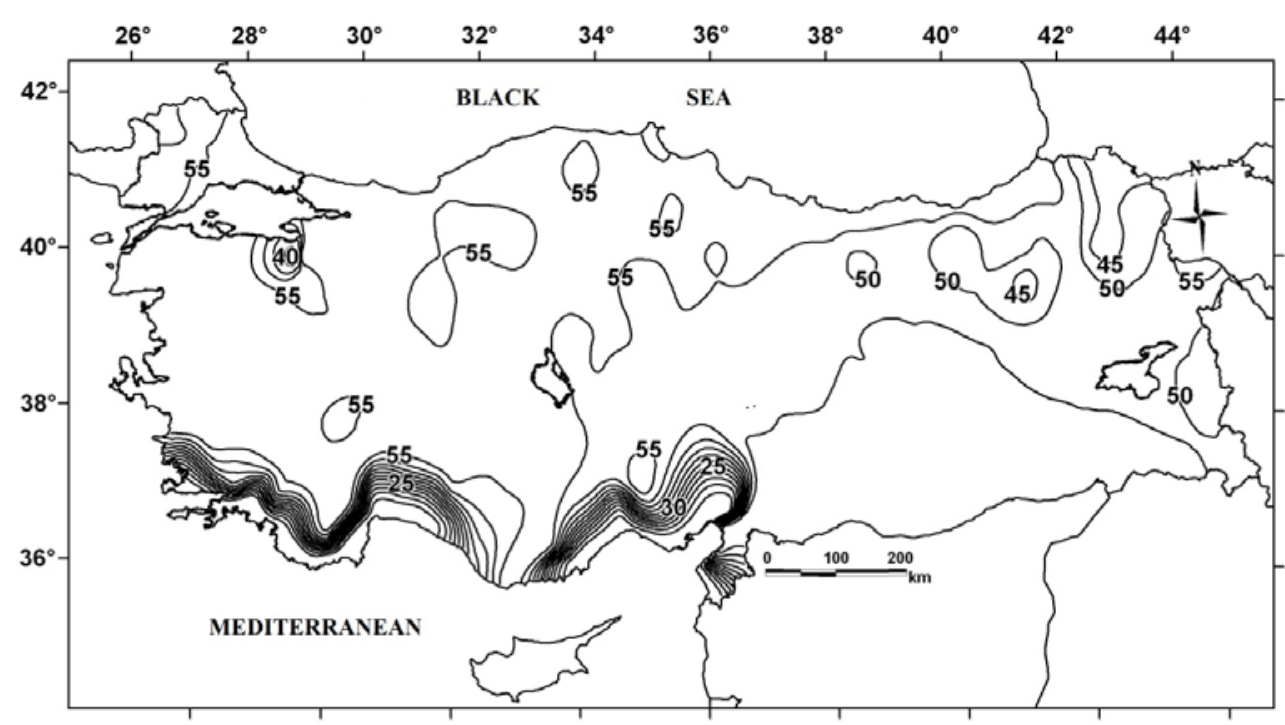

Fig 9. Spatial distribution of snowy days in 3-month autumn season: coefficient of variation (\%).

\section{Annual}

Although the determination of mathematical seasons is based on 4-month periods, mathematical seasons sometimes do not reflect the natural seasons as experienced in reality. In determining the natural seasons, the factors which may cause change in the characteristics of the season in reality include latitude pressure systems, air masses, continentality (continental vs. maritime climate), air temperature types, location, altitude and exposure (Koç 1999). When looked at from this perspective, Turkey, as a country where physical geographic features exhibit significant changes over short distances, does not experience all four seasons. Depending on unique conditions in some areas, spring has the features of being a continuation of winter, and in some areas winter is the continuation of autumn. There is an interesting resemblance between Turkey's annual snowfall days distribution map and the winter snowfall days distribution map. Hence, it is considered that the annual map is the one most affected and represents results obtained in winter (Fig. 10).

In the annual map, the highest number of snowfall days is observed in the following areas: The eastern Black Sea mountains, northeastern Anatolian plateau, Tahtal1-Mercan mountain ranges (Anatolian Diagonal), Taurus Mountains and areas near Hakkari (Fig. 10). The mountainous regions where the number of snowfall days is high extend westwards with the western Black Sea mountains and become significant especially in Kastamonu and its environs. Central-western Anatolian plateaus are also areas where the number of snowfall days increases.

Regarding annual distribution, the coastal strips of the Mediterranean and Aegean were also determined as areas where little or no snowfall is observed. The southeastern Anatolian region is notable as an area where the number of snowfall days increases, compared to the Mediterranean and Aegean regions, due to its continental climate (Fig. 10).

As mentioned, the increase in the number of snowfall days in the Taurus Mountains and its surroundings is thought to be the result of increased precipitation due to exposure, which takes the form of rain in the coastal strip and snow at high altitudes (Fig. 10). In Figure 11, which presents the annual spatial distribution of the coefficient of variation of snowfall days, a significant increase is observed from the northeast toward the south west, similar to that experienced in all seasons in Turkey. In a similar fashion, in areas where factors increasing the probability of snowfall (location, continentality, altitude, exposure) are more effective, it is observed that the coefficient of variation of the number of snowfall days decreases, while this coefficient of variation increases under opposite conditions (Fig. 11). 


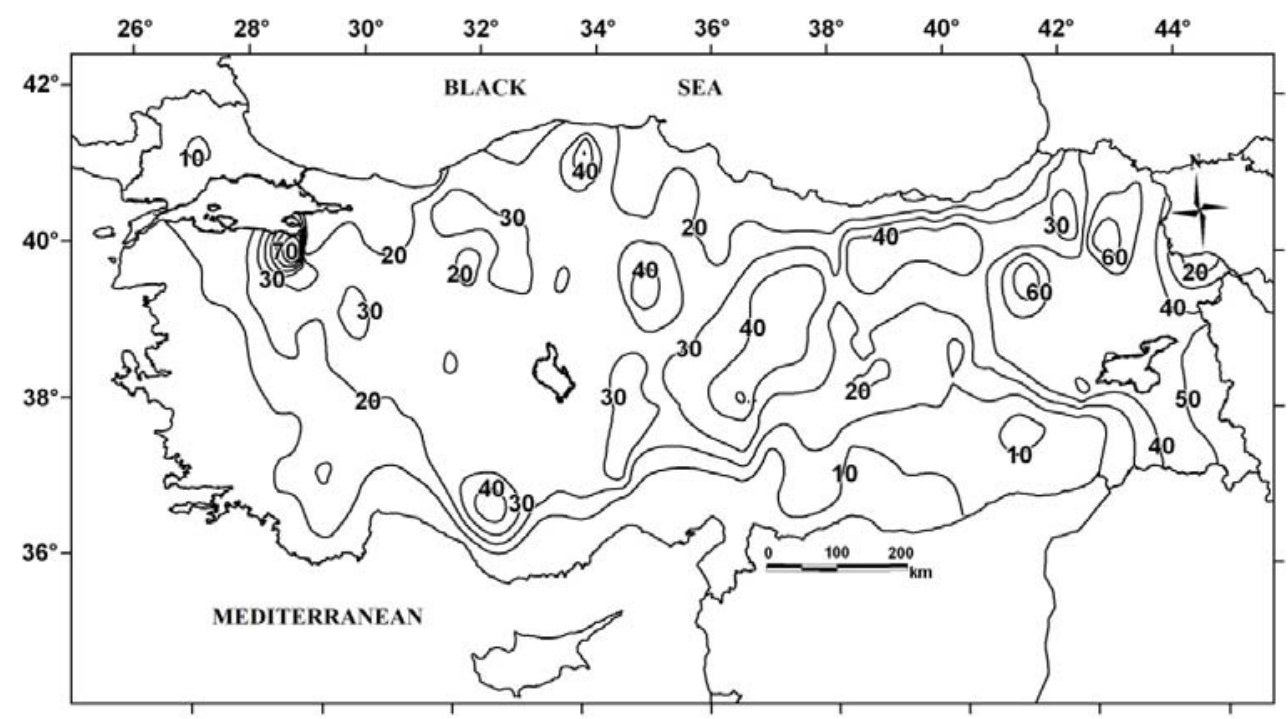

Fig 10. Spatial distribution of annual snowy days in Turkey: long-term average number of days.

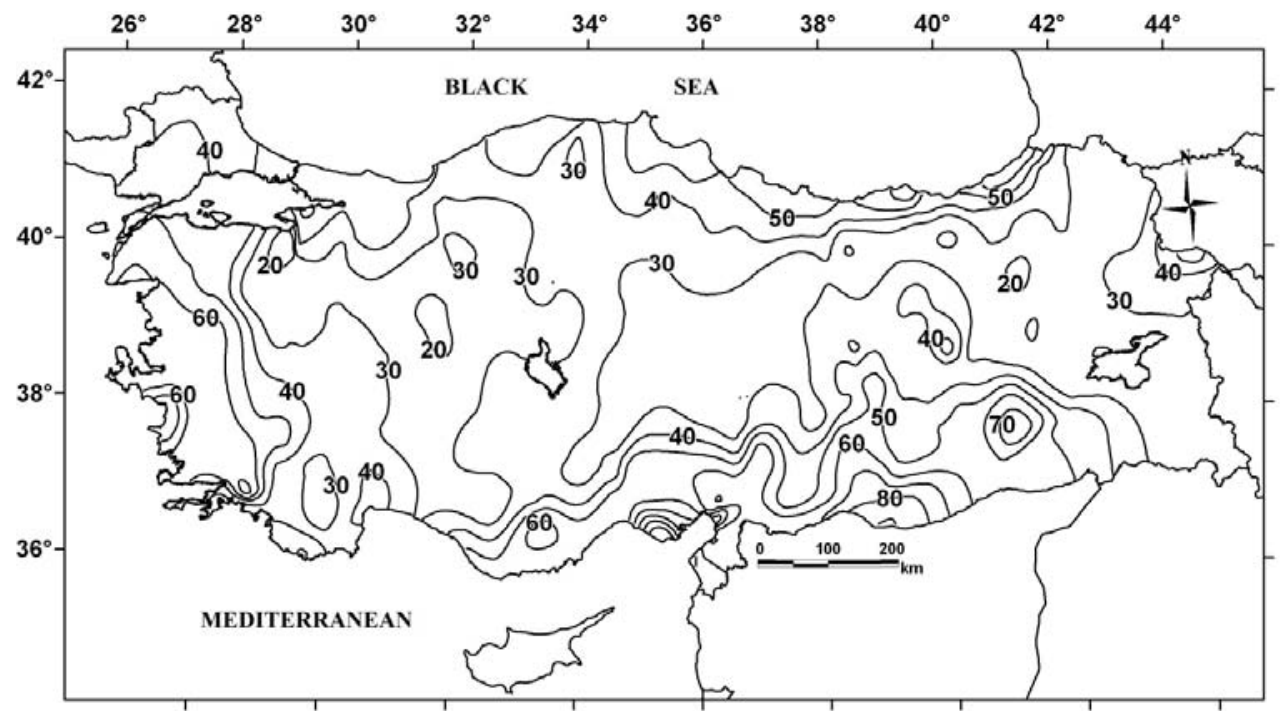

Fig 11. Spatial distribution of annual snowy days in Turkey: coefficient of variation (\%).

\section{Conclusion}

An appraisal of the snow climatology is essential for an understanding of the climatic characteristics in Turkey, where there is a lack of up-to-date and reliable analysis on snow climatology. As a starting point to rectify this deficiency, we attempted to identify the characteristics of snowfall days. In this study, based on daily data, the seasonal and annual snowfall days and their coefficients of variance were determined. In preparation of the data, it was found that, in terms of spatial distribution, the number of snowfall days increases from west to east and from south to north. When local conditions are taken into account, it is observed that in some specific areas in the west (e.g. Mt. Uludağ) the number of snowfall days is higher compared to some areas in the east (e.g. Iğdır), contrary to what is generally expected. Moreover, since the air masses causing snowfall approach Turkey from the northern part of the country, the northern slopes of northern mountains receive more snowfall while the lower parts and southern slopes are less affected by these air masses. 
The conclusions of the study may be summarized as below:

a. The factors that control the spatial distribution and variance of snowfall days in Turkey are, in order of importance, location, continentality, altitude and exposure.

$b$. The period that reflects best the spatial distribution of snowfall days in Turkey and the coefficient of variance is the winter period. The characteristics of this period can be stated as follows: Distribution of snowfall days increases from the southeast toward the northwest and elevated values are occasionally observed on high mountains. In line with this, the coefficients of variance decrease from northeast to southwest.

c. It is not possible to make a healthy analysis of snowfall days in summer and their coefficients of variance.

$d$. Especially in eastern and central Anatolia, the spring season may be characterized as a continuation of winter.

$e$. Although snowfall started to be observed in northeastern Anatolia and areas of high altitude in autumn, where the factors that increase the possibility of snowfall are stronger, the coefficient of variation is high in these places. Since no snowfall is observed in areas toward the Mediterranean region in this season, the coefficient of variation is low.

\section{Acknowledgements}

This research was supported by a Turan Demirarslan grant from the Turkish Foundation for Combating Soil Erosion, for Reforestation and the Protection of Natural Habitats (TEMA). This study was also supported by Çanakkale Onsekiz Mart University, Scientific Research Projects (SRP) (project no: 2009/100). We would like to thank the SRP and TEMA for their financial support.

\section{References}

\section{Article in Journal:}

Akyürek Z., Şorman AU. 2002. Monitoring snow-covered areas using NOAA-AVHRR data in the eastern part of Turkey, Hydrological Sciences Journal - Journal Des Sciences Hydrologiques, 47 (2): 243252.
Brown RD. 2000. Northern hemisphere snow cover variability and change, 1915 - 97, Journal of Climate 13 (13): 2339-2355.

Barry RG, Fallot JM, Armstrong RL. 1995. Twentieth-century variability in snow-cover conditions and approaches to detecting and monitoring changes: Status and prospects, Progress in Physical Geography 19 (4): 520532.

Crurch JE. 1933. Snow surveying: Its principles and possibilities, Geographical Review, Vol. 23, No. 4. (Oct. 1933), pp. 529-563.

Demircan M, Çiçek İ, Türkoğlu N, Ekici M, Arabacı H, Akçakaya A. 2015. Ortalama sıcaklıklardaki türdeşlik kırılmalarının iklim göstergeleriyle ilişkisi, VII. Atmospheric Science Symposium, 28-30 April 2015 İstanbul, Bildiri Kitab1, 605-614, İstanbul.

Erinç S. 1957. Tatbiki Klimatoloji ve Türkiye'nin İklim Şartları, İstanbul Teknik Üniversitesi, Hidroloji Enstitüsü Yayını S:2 İstanbul.

Gürer İ. 1992. Kar Hidrolojisi, I. Coğrafya Meslek Haftası, Kasım 1991, İzmir, ss. 99115.

Kartum Ş, Koç T. 2009. Trakya'da su kaynaklarının sürdürülebilir kullanımında kar yağışlı günlerin etkisi, I. Trakya Bölgesi Kalkınma ve Girişimcilik Stratejileri Sempozyumu 16-18 Ekim, Edirne, Bildiri Kitab1, 219-228.

Kartum Ş, Koç T, Türkeş M. 2011. Türkiye'de kar yağışlarının başlangıç ve bitiş tarihlerinde gözlenen değişiklikler ve eğilimler, In: 5th Atmospheric Science Symposium Proceedings Book, Istanbul Technical University, 27-29 April, 195-200.

Klein GJ. 1949. Canadian survey of physical characteristics of snow-covers, Geografiska Annaler, Vol. 31, Glaciers and Climate: Geophysical and Geomorphological Essays. pp. 106-124.

Koç T. 1999. Sayılı günler yöntemi ile doğal mevsimlerin belirlenmesi, Ege Coğrafya Dergisi, say1: 10, s: 305-344, İzmir.

Koç T, Kartum Ş. 2008. Türkiye'de kar yağışlı günlerin özellikleri ve dağılışı, TUCAUM V. Ulusal Coğrafya Sempozyumu Bildiri Kitab1, Ankara 16-17 Ekim 2008, Ankara Üniversitesi DTCF, 339-348, Ankara 2008.

Koç T, Kartum Ş. 2011. Türkiye'de kar yağışlı günlerin zamansal değişim özellikleri, 
Uluslararası Katılımlı Coğrafya Kongresi 710 Eylül, İstanbul.

Komisyon. 1970. Türkiye'nin kar örtüsü etüdü, Devlet Meteoroloji İşleri Genel Müdürlügüu, E. A. No: 39 teksir atölyesi (A.1000) 9.70, Ankara.

Laternser M, Schneebeli M. 2003. Long-term snow, climate trends of the Swiss Alps (1931-99), International Journal of Climatology 23 (7):733-750.

Onur A. 1964. Türkiye'de Kar Yağışları ve Yerde Kalma Müddetleri Üzerine Etüd, Ankara Üniversitesi, Dil ve Tarih-Coğrafya Fakültesi Yayınları, No: 152.

Öngör S. 1955. Kar yağışları ve meteorolojisi hakkında not, Türk Coğrafya Dergisi 13-14.

Öztürk K. 2002. Küresel iklim değişikliği ve Türkiye'ye olası etkileri, G.Ü. Gazi Eğitim Fakültesi Dergisi, Cilt 22, Sayı 1, Sayfa 4765.

Türkeş M. 2001. Hava, iklim, şiddetli hava olayları ve küresel ısınma, T.C. Başbakanlık
Devlet Meteoroloji İşleri Genel Müdürlüğü 2000 Y1lı Seminerleri, Teknik Sunumlar, Seminerler Dizisi: 1, 187-205, Ankara.

Türkeş M. 2004. İklimsel ve atmosferik verilerin türdeşlik ve rasgelelik çözümlemesi, Temel İstatistik Kursu Notları, T.C. Çevre Bakanlığı, Devlet Meteoroloji İşleri Genel Müdürlügüü, Ankara.

Türkeş M. 2008a. Ekolojik, ekonomik, politik bir sorun iklim değişikliği, Mülkiye Cilt: 32, say1: 259, s: 101-131, Ankara.

Türkeş M. 2008b. İklim değişikliği ve küresel ısınma olgusu: Bilimsel değerlendirme, Küresel Isınma ve Kyoto Protokolü, s: 2157, Bağlam yayıncılık, İstanbul.

Yüzer AF, Ağaoğlu E, Tatlıdil H, Özmen A, Ş1klar E. 2003. İstatistik, T.C. Anadolu Üniversitesi Yayını, no: 1448, Eskişehir. 